\title{
EVANGELIZAR EN TIEMPOS DE INCREENCIA
}

\author{
Miguel Ángel Núñez Aguilera \\ Centro de Estudios Teológicos - Sevilla
}

\section{RESUMEN / ABSTRACT}

Inmersos en un ambiente socio-cultural impregnado por la increencia, el creyente se encuentra hoy fuertemente confrontado: convocado para anunciar a Dios a sus contemporáneos, y a un tiempo persistentemente rechazado por ello. De ahí que sea una urgencia reflexionar sobre cuáles son las claves antropológicas del hombre contemporáneo que le han conducido a tal cerrazón en su estructura intima hasta instalarlo en la increencia. El presente artículo aborda no sólo en el por qué el anuncio cristiano no interesa al hombre contemporáneo, sino, más radicalmente, por qué Dios ha dejado de ser significativo al hombre. Y también algunas consideraciones desde dónde proponer la fe hoy, alcanzar nuevos caminos para el anuncio del Evangelio.

Immersed in a socio-cultural environment based on the unbelief, the believer faces a strong controversy nowadays: s/he is called to announced God to his/her contemporary people, being constantly avoided by such reason. Therefore, it is an urgency to make a reflection about the anthropological keys that drive men to such a strong internal position that place them in the unbelief. This paper does not only study why the Christian message does not interest to contemporary men but, more radically, why God has stopped being significant to men. We also make some considerations about where to propose the faith today, reaching new ways of announcing the Gospel. 
¿Cómo mostrar a Dios en tiempos de increencia? La pregunta brota espontánea en el corazón creyente. Enviado al mundo para anunciar lo que ha visto y oído, el creyente pronto es confrontado fuertemente en sus convicciones por las dificultades reales que experimenta para comunicar su fe. Por otra parte, a estas situaciones de rechazo o de indiferencia ambiental, hay que sumar el dolor íntimo que vive el creyente cuando constata que aquel que es protagonista indiscutible de la vida, Dios, no interesa en modo alguno, ha dejado de ser referencia constitutiva de vida. En efecto, para un gran número de nuestros coetáneos, Dios (aún más, la mera referencia a lo divino o lo trascendente) no forma parte en modo alguno de su comprensión vital. La cuestión de la evangelización así planteada contiene dentro de sí la percepción intuitiva de su propio drama: por una parte, la afirmación Dios, que para el creyente conforma la certeza de una presencia incuestionable, y por otra, la comprobación de un universo humano donde Dios ha sido descartado. Pues, "para muchos de nuestros contemporáneos, el tiempo de Dios habría de considerarse prácticamente cancelado"1; un asunto sencillamente periclitado.

En estas circunstancias, donde la sola pregunta por Dios ya se sitúa bajo el signo de su negación, la constante exigencia comunicativa de la fe para el creyente (cfr. 1 Pe 3,15-16) se enfrenta a un salto cualitativo: la falta de receptibilidad activa del interlocutor, su rechazo positivo y previo a cualquier propuesta creyente. Nos encontrariamos con un paradigma antropológico, stricto sensu, de ateísmo como postulado supuesto ${ }^{2}$ en la composición vital de la existencia. Ante este hecho radical donde se ha producido tal extrañamiento en la comunicación, el creyente puede sentirse arrastrado desde la imposibilidad comunicativa a un cierto sentimiento de impotencia. Un proceso de interiorización del rechazo que amenaza por afectar la propia condición del testigo de la fe, cargándolo emotivamente por el peso de la negativa ambiental. Diriamos entonces que nuestra pregunta inicial, ¿Cómo mostrar a

Santiago DEL CURA ELENA, A tiempo y destiempo. Elogio del Dios (in)tempestivo, en "Burgense" 43/2 (2002) 327.

2 Cf. Fernando SEBASTIÁN AGUILAR, Pastoral de la increencia, Seminarios 58 (2012) 20. 
Dios en tiempos de increencia?, deja de ser entonces expresión de vigor evangelizador para revestirse de un cierto desaliento ante la incapacidad que siente el creyente para hacer llegar su mensaje al hombre de hoy ${ }^{3}$. La pregunta entonces ya no espera respuesta, se ha convertido en retórica. Tal percepción no es neutra, y puede generar efectos perversos en el evangelizador: la interiorización de una incapacidad comunicativa para la fe, la admisión implícita de su irracionalidad; o aún peor, la abdicación no confesa de la pretensión universal de Salvación en Jesucristo, a la luz de tantos como viven sin Él, y tampoco parecen echarle de menos.

Dios ha dejado de percibirse y afirmarse en su ser luz sobre la intima verdad del hombre, para desplazarse al mundo de las emociones, según sensibilidades o necesidades psicológicas. En este desplazamiento del lugar antropológico de Dios en el hombre, el binomio Dios-hombre eje de toda la economía de la salvación que constituye el dinamismo propio de la Revelación queda roto. Dios aparece ahora exterior y extraño a lo humano, superficial o accesorio para entender qué es el hombre. En cualquier caso, no necesario al hombre, totalmente prescindible para la existencia. De tal modo, que la relación creyente hombre/Dios no sería más que una sensación subjetiva que algunas personas desarrollan para dar sentido a su vida o encontrar una satisfacción psicológica ante ciertas realidades vitales. Aunque estos procesos de ubicación comprensiva de la existencia y de la trascendencia se produzcan de modo inconsciente, no por ello dejan de ser menos efectivos, y sus consecuencias pueden ser devastadoras, pues cortan de raíz la comunicación natural que en el seno de la comunidad eclesial siempre se ha vivido y afirmado entre el anuncio del Evangelio -revelación de Dios-, que es la persona misma de Jesucristo, y la verdad primera y última del hombre, tal como bellamente expresó la patrística por boca de san Ireneo: "Gloria Dei homo vivens et vita hominis visio Dei"'.

En el presente artículo, al tiempo que nos sentimos cercanos a los esfuerzos de tantos evangelizadores en su ardor apostólico, pese

3 Cfr. Juan MARTÍN VELASCO, ¿Dónde está Dios? Itinerarios y lugares de encuentro, Madrid, Verbo Divino, 1998, 38-41.

4 IRENEO, Adversus haereses, IV, 20, 5-7. 
a la aridez del momento presente, queremos tomar la pregunta '¿Cómo mostrar a Dios en tiempos de increencia?' en su audacia primera para reflexionar y recorrer desde la fe los caminos que puedan ayudarnos a mostrar el Dios vivo y verdadero al hombre contemporáneo sumido en la denominada increencia. Nuestra primera cuestión, por tanto, será indagar en las raíces de esta negación. No sólo en el por qué el anuncio cristiano no interesa al hombre contemporáneo, sino, más radicalmente, por qué Dios ha dejado de ser significativo al hombre, ha dejado de operar como su verdad más íntima en la definición de lo humano.

\section{HACIA UNA TEMATIZACIÓN FENOMENOLÓGICA DE LA INCREENCIA}

Desde el ateísmo filosófico, hasta la mera y pasiva indiferencia del hombre de a pié, pasando por el ateísmo práctico y la pretendida asepsia de quien se declara agnóstico, pero que ya ha incorporado una sospecha sobre Dios en su horizonte intelectual y vital, el abanico de posicionamientos ante la pregunta ¿Dios? es amplísimo. Sin embargo, frente a todos ellos, la llamada increencia no sería propiamente un fenómeno descriptivo de negación de Dios, sino más bien una negación antropológica para la fe. No se niega la existencia de Dios, sino que lo que se niega es la respuesta humana en su base: la entrega de mi fe. La increencia como término catalizador del presente humano respecto a Dios sólo tendría en común con el ateísmo o el agnosticismo su visión antropológica cerrada a la trascendencia. Por ello, para adentrarnos con acierto en una cuestión tan compleja en su fisonomía es conveniente delimitar sus contornos con algunas precisiones:

a) Si bien en la actualidad los procesos de negación de Dios revisten formas menos precisas que décadas atrás, donde la crítica al cristianismo ya no es su elemento fundacional, el fenómeno, en su raíz, se asienta sobre los denominados Maestros de la Sospecha en su rechazo a la cosmovisión cristiana que había conformado su cultura y su tiempo. Así considerada, la increencia deja de ser neutra. En su genética porta un constitutivo anticristiano, que bien puede explicar la cristofobia de ciertas manifestaciones artísticas o el sesgo manifiestamente contracristiano de 
pensadores y creadores de opinión, pese a haber crecido ya en contextos culturales no marcados por el cristianismo, o incluso abiertamente laicistas. En ellos parece rezumar una cierta retroalimentación en el rencor por el Dios no vencido, pese a haber decretado su muerte. De donde podemos advertir, que el fenómeno de la increencia, lejos de manifestar un perfil pasivo in-creencia (el hecho de no creer o vivir sin creer), encierra una posición activa y positiva contra el creer.

b) La textura confusa y carente de argumentos de la increencia, hacen de la negación del creer un fenómeno más práctico que teórico, más sentimental que racional. De tal modo, que la increencia es asumida por el hombre contemporáneo más por razones extrinsecas, como un elemento ingrediente de modernidad, que por convicciones interiores. La increencia vendria a ser como una especie de pose estética -no razonada- del hombre contemporáneo, que le permite autopercibirse sin ataduras y presentarse en sociedad libre y absolutamente abierto... incluso de cualquier vinculación trascendente. Un hombre abierto respecto de cualquier referencia constitutiva y fundante de su ser.

c) Tras el fracaso de los grandes postulados ideológicos del proyecto antropológico ateo que conformaron Occidente durante el siglo XIX y XX (muerte de Dios y dominio de la materia), vacíos en su contenido ya sólo se sostienen en su apariencia. Es la extensión de la ideología en lo políticamente correcto, donde las afirmaciones de razón y sus argumentos son sustituidos por la consigna y la propaganda. Los postulados de increencia instalados en el pensamiento socialmente compartido han conducido progresivamente al silencio del alma humana en torno a la proposición Dios, generando una atmosfera de silencio o pacto tácito de no afirmar/cuestionarse. "Este pacto de silencio sobre Dios, poco a poco, va confirmando el ateísmo de los ateos y debilita la fe de los creyentes. Lo que comienza siendo un silencio concedido termina siendo un silencio convencido. En el fondo late la convicción de que Dios no interviene en nuestra vida" . Tal como agudamente afirma Fernando Sebastián, antes que una

5 Fernando SEBASTIÁN AGUILAR, Pastoral de la increencia, 20. 
negación de Dios, hoy se empieza por vivir en ausencia de Dios y luego se buscan razones para justificar este comportamiento. Tal vez sea el silencio del alma el rostro más siniestro de esta cultura de la increencia porque despoja al hombre de toda posibilidad de sentido trascendental, y de su más intima esperanza.

d) Después de eliminar la presencia de Dios en el discurrir de lo cotidiano del existir humano, donde se le juzgó como una amenaza para la convivencia, ahora aparece fuertemente la cultura de la increencia como instancia garante de la convivencia. Sólo desde una exclusión de Dios del orden de las relaciones humanas, sería posible una sociedad integradora para todos. De algún modo, los postulados de la increencia ahora se afirman implícitamente como principio normativo previo de las relaciones sociales: como no todos creen, los creyentes deben relacionarse y adoptar pautas de comportamiento como si no creyesen. Diríamos toscamente que la increencia se ha levantado en nuestra cultura occidental como la religión oficial del Estado, y de los estados. Baste constatar la legitimidad desigual que presenta la no creencia respecto de la creencia en foro público, sede parlamentaria o discurso político. Si bien la posición no creyente está legitimada en discurso público, una afirmación vital humana que incorporase la fe sería considerada improcedente, inapropiada, y en última instancia abusiva. Tal vez aquí radique la dificultad creciente que progresivamente se impone en los ordenamientos jurídicos para amparar y reconocer algunos derechos, incluso el mismo derecho de objeción. A la vista de la dificultad creciente para ejercer su legítimo derecho a la objeción de conciencia de tantos ciudadanos, parece intuirse en el cuerpo legislativo un artículo invisible que parece sancionar un "salvo por motivación de fe". De este modo, se fija en el común social la creencia de que el estado de increencia es el que más y mejor se ajusta al estado social de relación y convivencia que es la democracia.

e) Por otra parte, el fenómeno de la increencia tiene su génesis, no sólo en países de tradición cristiana, sino que su amplia difusión entre una población catequizada y admitida a los sacramentos nos sitúa, al menos técnicamente, ante un fenómeno distinto: la apostasía. Ésta si bien no es formal, más que en algunas minorias muy escoradas ideológicamente, sí es material en grandes sectores 
sociales como Juan Pablo II señalara ${ }^{6}$. Este hecho debe llevarnos a una reflexión sobre la pastoral ordinaria entre las iglesias de vieja cristiandad, y específicamente sobre los modos y procesos de transmisión de la fe que en ellas se dan. De algún modo, el fenómeno de la increencia nos coloca ante la crítica de nosotros mismos en nuestro hacer evangelizador como la conversión no alcanzada ${ }^{7}$. Tal vez, en la trasmisión de la fe, frecuentemente hayamos olvidado que la evangelización alcanza su verdad en la conversión tal como nos recuerda la liturgia al inicio de cada cuaresma: "Conviértete y cree en el Evangelio".

f) Paradójicamente, el fenómeno de la increencia ha traído consigo un renacer de formas religiosas y un auge del sentimiento espiritual, que busca en el sincretismo de los distintos elementos que ofrecen las grandes religiones su acomodo, o buscan cauce en la nebulosa informe de recursos psico-espirituales que genéricamente se ha dado en llamar New Age. Sin embargo, la denominada revancha de Dios ${ }^{8}$, que algunos ven con simpatía como si la puerta a la trascendencia se volviera a abrir, no es propiamente un redescubrimiento de la presencia de Dios, al menos, del Dios trascendente, sino más bien una proyección inmanente del sentir religioso. "Una reviviscencia de lo religioso en multiplicidad de metamorfosis, una expansión

6 "La cultura europea da la impresión de ser una apostasía silenciosa por parte del hombre autosuficiente que vive como si Dios no existiera". JUAN PABLO II, Ecclesia in Europa, $\mathrm{n}^{\circ} 9$.

7 "Después de la guerra civil se estableció en España un régimen confesional que con el tiempo ha debilitado la credibilidad de la Iglesia ante muchos españoles. Por una parte la práctica cristiana, cuando es impuesta como única y obligatoria, se hace odiosa para muchas personas que no se sienten a gusto con ella. Por otra parte, al ser una religión protegida, se debilita la fuerza de la adhesión personal. Los católicos poco a poco se van volviendo rutinarios, comodones, tibios. Y a la vez los no católicos se sienten reprimidos, discriminados y se radicalizan en su rechazo de una fe y de unas instituciones que ellos perciben como impuestas, autoritarias, e injustas". Fernando SEBASTIÁN AGUILAR, Pastoral de la increencia, 23.

8 Los fenómenos asociados a este proceso, según el propio creador del concepto, son el fundamentalismo religioso y las nuevas formas religiosas recuperadas de la antigüedad que conformarian el neopaganismo. Dos índices lo suficientemente elocuentes como para desconfiar de este pretendido redescubrimiento de Dios. Fundamentalismo e idolatría excluyen la verdad de Dios tal como es confesada en el cristianismo. El primero porque excluye al hombre, la segunda porque excluye a Dios. Cfr. Gilles KEPLER, La revancha de Dios. Cristianos, judios y musulmanes a la reconquista del mundo, Salamanca, 1991. 
de espiritualidades plurivalentes, que, en sus manifestaciones, parecen alimentar una cierta contraposición entre religión (si) y Dios (no)" 9 . En cuyo caso, estariamos ante una situación de gran complejidad para el espíritu humano que ha encontrado en los sucedáneos de la religión un refugio donde huir de sí mismo y de sus insatisfacciones, una cierta expresión de rebeldía del hombre ante el dominio de la materia que lo asfixia, y una versión de la religión como producto de consumo.

g) Finalmente, y en contra de cierta impresión localista occidental, el fenómeno de la increencia no se corresponde con la globalidad del hecho religioso en el mundo contemporáneo, que curiosamente vive días convulsos de matriz religiosa a causa del fundamentalismo islámico o hinduista. Más bien, las reacciones virulentas de estos grandes bloques humanos nos permite afirmar que lo religioso, la religión, todo aquello que media el trato de los hombres con Dios, o los dioses en el mundo politeísta, es altamente significativo. Aun más, la increencia como diagnostico sociológico tampoco parece corresponderse con el sentir mayoritario de sociedades sudamericanas, africanas o asiáticas, donde la preeminencia del sentir religioso en los ritmos personales y sociales contradicen nuestro juicio sobre el presente como tiempo de increencia ${ }^{10}$. Nos encontramos, más bien, ante un fenómeno típicamente occidental en su más amplio sentido, gestado durante la modernidad por el pensamiento europeo, y que ha alcanzado su máxima difusión en la Europa postmoderna. No obstante, debemos admitir que la posición hegemónica de Occidente en un mundo globalizado está siendo determinante para la rápida difusión del fenómeno al resto de sociedades.

En conclusión, cuando hablamos de increencia nos referimos a un fenómeno culturalmente occidental, que tiene su génesis en países de tradición cristiana como rechazo al cristianismo que lo

9 Santiago DEL CURA ELENA, A tiempo y destiempo. Elogio del Dios (in)tempestivo, 327.

10 El estudio Bertelsmann revela una curiosa inversión del sentir religioso y la relevancia de Dios en sus vidas entre jóvenes europeos y jóvenes asiáticos, africanos o americanos. Cfr. Encuesta mundial sobre el hecho religioso Fundación Bertelsmann, julio 2013. 
conformó durante siglos; aunque en gran difusión por la hegemonía de Occidente sobre los medios de comunicación y el pensamiento, sobre la política y la economía globalizada. Recoge dentro de sí posicionamientos muy diversos ante la cuestión Dios, aunque con un denominador común: una visión antropológica cerrada respecto a la trascendencia. Esto no supone una eliminación absoluta de lo religioso en el hombre, tal como podría pensarse, sino su deformación inmanente como atestiguan las nuevas formas de expresión religiosa basadas en el sincretismo, la recuperación de los cultos ancestrales, y la New Age.

\section{LA INCREENCIA COMO EFECTO, NO CAUSA}

La increencia en su radicalidad antropológica, como cerrazón del existente humano a cualquier forma de trascendencia, es una realidad relativamente nueva, que supone un salto cualitativo del fenómeno sobre el escepticismo filosófico clásico. Como señala Maria Zambrano, "hace muy poco tiempo que el hombre cuenta su historia, examina su presente y proyecta su futuro sin contar con los dioses, con Dios"11. Esta ausencia radical de trascendencia en el horizonte humano va más allá del ateísmo filosófico clásico, o al rechazo de una determinada confesión religiosa. La moderna increencia afecta a la misma constitución interna del binomio DiosHombre, al cómo la trascendencia afirma la inmanencia, y más propiamente al existente humano, y al cómo la inmanencia refiere, en su verdad intima, una realidad que no es ella misma, que le rebasa y la eleva. Un proceso que tiene su cuna en la modernidad.

Tras la desnaturalización de Dios hasta su reducción metafísica, y consiguiente cosificación ontológica en los siglos inmediatamente anteriores al racionalismo ilustrado, se llegó a un pensar a Dios como no Dios ${ }^{12}$ : Dios-concepto. Esto es, "Dios en el mismo plano que

11 Maria ZAMBRANO, El hombre y lo divino, Madrid, Fondo de Cultura Económica, 1993, 12.

12 Se piensa a Dios sin historia (alianza), sin mundo (creación), sin hombre (encarnación). Cfr. Olegario GONZÂLEZ DE CARDEDAL, La entraña del cristianismo, Salamanca, Secretariado Trinitario, 1997. 111-125. 
los demás objetos de la razón, pero no verdaderamente otro"13. Las funciones ontológicas del Ser que vinculaban constitutivamente al hombre en su estructura íntima con Dios, en la autocomprensión que de sí mismo hace el hombre moderno, fueron progresivamente asumidas por él hasta llegar al sujeto contemporáneo, que ahora se autopercibe como artífice y origen de su propio ser, y aún de la realidad que lo circunda. Así, cuando Descartes sitúa el principio de verdad en el cogito está dando lugar a una verdadera revelación del hombre mediante la razón, ahora constituida en absoluto. $\mathrm{Su}$ afirmación 'cogito ergo sunt' desvela un hombre autoremitido, que se revela a sí mismo como origen de su existir, sin necesidad ni referencia a otro ser fundante. El hombre logra alcanzar la evidencia de su existencia como propia, en cuanto afirmación de su racionalidad, sin necesidad alguna de remisión trascendente.

En esta nueva percepción del hombre que se afirma a sí mismo en su existencia, como origen irrefutable de sí, Dios queda reducido a mero garante de las percepciones exteriores, pero que ya ha dejado de ser principio necesario para el existir humano. Un proceso que culminará en Kant, cuando la realidad pierda su consistencia en sí para ser objeto de pensamiento. Será entonces cuando el hombre no sólo se afirme a sí mismo con independencia de otro Ser fundante, sino que la misma realidad es en tanto que afirmada por el sujeto. El hombre que ya había alcanzado su autonomía respecto de cualquier principio fuera de sí con Descartes, ahora con Kant deja de sentirse atado a la realidad, que se verá reducida a objetos de su pensamiento y manipulación. E1 acto originario de creación de cuanto existe por parte de Dios, sobre el que descansaba la comprensión clásica del hombre desde la antigüedad judeo-cristiana, es ahora sustituido por una recreación a cargo del hombre. Este nuevo existente humano, que ya no se comprende desde la remisión al Creador, se siente impelido a protagonizar una nueva creación de todas las cosas que tenga como eje la sola determinación humana. Es la comprensión del sujeto como principio absoluto que va a protagonizar una creación absoluta de todas las cosas en él. Es el sujeto quien crea el sentido de la realidad y construye su mundo mediante la historia, ahora

13 Jean DANIÉLOU, Dios y nosotros, Madrid, Cristiandad, 2003, 83. 
vivida como progreso en cuanto despliegue-encarnación de su subjetividad. Justamente este es el concepto filosófico desplegado por Hegel. La historia intelectual, social y politica posterior tendrá este presupuesto: el hombre es el Dios de la nueva creación. Como resultado de este proceso, Dios queda exterior a la existencia de los hombres y del mundo; es un extraño revelado ante el cual sólo queda la posibilidad de la piedad como vía de acceso al rostro de Dios. Lo cual explica muy gráficamente que los siglos derivados del racionalismo sean a su vez los del auge del pietismo, y de todas las formas decimonónicas de piedad ${ }^{14}$.

Finalmente serán los denominados maestros de la sospecha quienes lleven a término el desenlace lógico de las premisas nacidas de la razón ilustrada, y reelaboradas por el idealismo alemán. Desde la no necesidad de Dios para la comprensión de la existencia, ahora se fijarán las bases de la necesidad de su no existencia para que el hombre pueda ser plenamente libre, soberano, sí mismo en el mundo. El círculo se ha completado. Si Dios ya no es necesario para afirmar al hombre, su sólo presencia constituye una amenaza, niega al hombre. Es necesaria la muerte de Dios para que el hombre viva, tal como describe Nietzsche en el advenimiento del Superhombre. Como describe lacónicamente María Zambrano, "la revelación de lo humano se cumple emancipándose de lo divino" ${ }^{15}$. Un nuevo paradigma había nacido, y Dios no figuraba en él. Es así como la negación de Dios deja de ser fruto de un posicionamiento personal para convertirse en marco de referencia colectivo y previo al individuo.

La cosmovisión del hombre moderno, y aún contemporáneo, ha sido sustancialmente trastocada en un sobre sí. Su umbral comprensivo ha sufrido una drástica reducción. Se ha internado al hombre en un universo cuyas puertas hacia la trascendencia han sido cerradas, una tras otra, sucesivamente todas. El hombre de la inmanencia en su pretensión de autonomía y afirmación, excluyendo

\footnotetext{
14 "Fue la reacción visceral de una conciencia que reclama un Dios vuelto al hombre y amoroso con él, en quien por tanto se pueda confiar y a quien se pueda amar". GONZÁLEZ DE CARDEDAL, La entraña del cristianismo, 116.

15 ZAMBRANO, El hombre y lo divino, 16.
} 
cualquier referencia transcendente, ha operado una verdadera reducción de lo humano, de lo que entiende de él mismo cuando se pregunta qué es el hombre. Se le ha privado de su capacidad de trascendentalidad. Diríamos que la negación de Dios efectuada bajo el racionalismo ha sido, en última instancia, reflexiva, desembocando en una íntima ofuscación de la definición del propio hombre ${ }^{16}$. El eclipse de Dios ha dejado sin luz al universo humano. En este sentido, se pregunta González de Cardedal: "El siglo por el hombre y contra Dios, ¿ha suscitado, junto con la negación de Dios, una nueva vida del hombre, o, por el contrario, muerte de Dios y muerte del hombre han ido unidas?"17. Paradójicamente con la autoafirmación radical y absoluta del hombre moderno, él mismo parece haber encontrado su propia muerte. Muerto Dios, la humanidad pierde a su interlocutor, un otro en relación que pueda afirmarlo en su ser. Ser criatura, ser persona, ser hijo, es impensable e imposible sin el reconocimiento del Creador, del Otro personal, sin Padre. A partir de ahora, el hombre quedará sumido en su existencia, donde historia, sociedad y progreso se viven como autodespliegue y explicitación de su racionalidad autoremitida. La increencia, así tomada, no sería propiamente un vivir natural y espontáneo de la persona sino un estado construido; pues como señala Cardedal, a la increencia "se llega y en ella se instala el hombre mediante reflexiones y decisiones, tras preferencias y concesiones" ${ }^{18}$.

\section{DE LA INCREENCIA A LA IDOLATRÍA: DEFORMACIÓN INMA- NENTE DE LA FE}

Paralelamente al fenómeno de la increencia ha surgido con creciente fuerza, hasta instalarse en el escenario social, una multitud de ofertas con decidida vocación religiosa: talleres de apoyo psico-afectivo, los más diversos gabinetes de paraciencias $\mathrm{u}$ ocultismo, el resurgimiento reinventado de cultos ancestrales, o la elevación a trato religioso de la naturaleza, del deporte, de la ciencia... Esta confrontación, tan sugestiva, de fenómenos

16 Cf. Fernando SEBASTIÁN AGUILAR, Pastoral de la increencia, 22.

17 GONZÁLEZ DE CARDEDAL, La entraña del cristianismo, 109.

18 GONZÁLEZ DE CARDEDAL, La entraña del cristianismo, 126. 
aparentemente contradictorios, entre increencia y adhesión ferviente a nuevas confesiones pseudoreligiosas, nos habla de un paradigma ambiguo; pues manifiesta que la increencia como una no-fe no sería del todo exacta. A la luz del rápido florecimiento de estos recursos sustitutivos para la fe, en una población que cultural y socialmente camina por la increencia, cabría pensar que el fenómeno de la increencia encierra dentro de sí dos polos: la negación antropológica para la fe, y al mismo tiempo, la deformación de la estructura antropológica del creer.

"Aunque Dios haya padecido supuestamente muertes sucesivas, no puede decirse que lo religioso y lo sagrado, (...) haya muerto del todo"19. En efecto, la trasmutación de trascendencia en inmanencia, efectuada durante la modernidad, no ha significado necesariamente la negación de la dimensión religiosa, sino más bien su cambio de polaridad. Tal como escribe Maria Zambrano en una de sus brillantes intuiciones: "Al abolirse lo divino como tal, es decir, como trascendente al hombre, él vino a ocupar su sede vacante" ${ }^{20}$, dando lugar a una nueva religión sin Dios, a la religión de lo humano. Lo cual explica bastante bien los perfiles hedonistas de nuestra sociedad, ya sea como culto al cuerpo o al éxito personal, ya sea como afán de dominio o de placer, o mediante cualquier otra forma de autosatisfaccción del ego. Estos fenómenos encuentran su explicación última en este proceso de suplantación inmanente de la dimensión trascendente del existente humano ${ }^{21}$. De tal modo que la perspectiva actual del hecho religioso ya no se sitúa ante su disolución más o menos previsible, sino ante la pervivencia y transformación de lo religioso en formas inmanentes de consumo y autosatisfacción. Lo que hemos venido en denominar, deformación inmanente de la fe.

Ya no es Dios quien determina constitutivamente al existente humano sino el hombre quien decide quién es Dios, y más propiamente qué es Dios, como señala Danielou: "Hacen de su

19 Santiago DEL CURA ELENA, A tiempo y destiempo. Elogio del Dios (in)tempestivo, 336.

20 ZAMBRANO, El hombre y lo divino, 20.

21 Señala Zambrano, "las manifestaciones de lo divino parecen corresponder a las situaciones más íntimas de la vida humana" ZAMBRANO, El hombre y lo divino, 125 
espíritu la medida de Dios" ${ }^{22}$. En efecto, el hombre inmanente buscará satisfacer su estructura básica de re-ligación por dos caminos: mediante su proyección en la historia y en la sociedad, dando lugar al progreso como idolatría, o bien, a través de remisiones a objetos de su mismo horizonte de inmanencia en un proceso ya descrito por san Pablo al hablar de la experiencia religiosa a través de lo creado y su deformación: "Pues lo que se puede conocer de Dios, lo tienen claro ante sus ojos, por cuanto Dios se lo ha revelado. Y es que lo invisible de Dios, su eterno poder y su divinidad, se ha hecho visible desde la creación del mundo, a través de las cosas creadas. Así que no tienen excusa, porque, habiendo conocido a Dios, no lo han glorificado, ni le han dado gracias, sino que han puesto su pensamiento en cosas sin valor y se ha oscurecido su insensato corazón. Alardeando de sabios se han hecho necios y han trocado la gloria del Dios incorruptible por representaciones de hombres corruptible, e incluso de aves, de cuadrúpedos y de reptiles. Es la consecuencia de haber cambiado la verdad de Dios por la mentira, y haber adorado y dado culto a la criatura en lugar de al Creador" (Rom 1, 19-23.25).

Irónicamente, la postulada increencia (no-fe) no habría liberado a la humanidad de una vida regida por Dios, sino que nos ha devuelto al mundo de los ídolos: El mirar intencional de un hombre cerrado en sí ("han trocado la gloria del Dios incorruptible por representaciones de hombres corruptibles"), no es capaz de visibilizar a Dios en su creación. La creación ha dejado de ser mediación, capaz de hierofanía, para constituirse en ídolo. Aquí podría radicar la recuperación y el auge de ciertos cultos ancestrales que conforman gran parte del neopaganismo emergente. Hace del mundo de su inmanencia ídolos con los que mantiene una cierta relación, una cierta satisfacción religante, a los que vincula su existencia. Pero debe afirmarse, en rigor, que en absoluto estamos ante un sentir religioso natural, sino ante una deformación inmanente de la fe. Pues como señala Daniélou, estas construcciones religiosas, aunque tengan su referente en elementos naturales, no son propiamente naturales "porque no expresan la revelación de Dios por medio de la naturaleza en estado puro, sino que siempre son elaboraciones" 23 .

22 DANIÉLOU, Dios y nosotros, 82.

23 DANIÉLOU, Dios y nosotros, 41. 
Nos encontramos con un tipo humano abismado en la inmanencia de su existencia. Tanto la transferencia de su anhelo hacia el futuro, como sus remisiones a elementos de su mismo plano de inmanencia, lejos de afirmarle en sus notas definitorias propias le reducen, le esclavizan, y finalmente le diluyen. Así, la remisión idolátrica a objetos de su misma inmanencia reducen su ser al orden de los entres cosas, donde el hombre pasa a ser uno más entre los elementos físicos del cosmos, y por la transferencia idolátrica al progreso deja de ser uno en sí para convertirse en medio, eslabón de un proceso necesario. Paradójicamente, el proceso de autoafirmación del hombre sin Dios ha desembocado en su reducción materialista, regido por la necesidad. El elemento persona desaparece porque si bien ante lo divino 'verdadero' el hombre se detiene, espera, inquiere, razona, ante lo divino extraído de su propia sustancia, el hombre queda inerte ${ }^{24}$.

Por otro lado, conviene subrayar que este resurgimiento de la actual idolatría tampoco se corresponde exactamente con el paganismo precristiano como propugnan algunas corrientes naturalistas. Algo así sería una falacia: el acontecimiento Cristo es un hecho, ha ocurrido. Muy por el contrario, los diversos fenómenos religiosos de polaridad inmanente no han obviado el legado cristiano sino que lo han integrado, seleccionando, reduciendo, asimilando, y finalmente adoptando como propio aquellos elementos más singulares del cristianismo como es la filiación divina. "La tragedia del pensamiento moderno -escribe González de Cardedal- consiste en haber retrocedido milenios identificando Yahvé con Júpiter, a Jesucristo con Prometeo, al mensaje de las Bienaventuranzas con un programa socrático o estoico, a la muerte de Jesús con un asesinato político, con un heroísmo moral o como mera consecuencia de un proyecto revolucionario" ${ }^{25}$. La absoluta y radical novedad del Evangelio ha quedado de este modo desactivada mediante su lectura inmanente: Cada cual puede tomar de él, e interpretar a su gusto, aquellos elementos de la fe cristiana que más se ajusten a su interés. Un proceso de alienación del Evangelio que discurre parejo al de expropiación de sus legitimos portadores

${ }^{24}$ Cfr. ZAMBRANO, El hombre y lo divino, 24.

25 GONZÁLEZ DE CARDEDAL, La entraña del cristianismo, 121. 
a lo largo de la historia, que conforma la tradición en el único sujeto Iglesia. De este modo, el dinamismo propio de la transmisión de la fe ha quedado doblemente afectado: La Palabra de Dios queda a la arbitrariedad del individuo, al tiempo que se ha cortado toda referencia a la tradición creyente, eclesial, depositaria de la misma. Paradójicamente, el seno eclesial donde han brotado los Evangelios y desde donde se han transmitido a lo largo de los siglos queda ahora ideológicamente descartado, y la Iglesia es señalada como el principal obstáculo para acceder a Jesucristo.

Pero, en una humanidad cerrada sobre sí y vuelta a la idolatría, cómo es posible la pervivencia del misterio de Dios. Desde dónde afirmar hoy el anuncio del Evangelio. Siguiendo las reflexiones de Danielou, aunque el hombre preso de su pecado de autosuficiencia establezca relaciones idolátricas con los elementos de su mismo horizonte inmanente, la naturaleza por ser criatura-participada no pierde su dimensión simbólica. Su misma constitución de ser creado la hace capaz de hierofania ${ }^{26}$. La valencia universal y permanente del lenguaje simbólico remite, como ha demostrado Jung, a un valor objetivo de los símbolos vinculados a la estructura misma del espíritu humano. En este sentido, Ladaria vuelve a ubicar al hombre en el centro del universo como su intérprete: "El Antiguo Testamento no vacila en considerar al hombre como el centro de la creación y como aquel ser en quien se descubre el sentido definitivo de todo lo que Dios ha hecho"27. La revelación cósmica y las diversas vivencias religiosas, aún en su deformación, ofrecen una gramática sin la cual no se entiende cómo el hombre pueda llegar a reconocer, entender y acoger la revelación positiva; el paso de la hierofanía a la teofanía. Diriamos que la deformación inmanente de su estructura antropológica de fe no ha cegado del todo la capacidad de Dios en el corazón del hombre, ni su deseo de Dios, ni su posibilidad para acceder a Él. La deformación para la trascendencia a la que nos ha inducido la modernidad no ha acabado con la verdad del hombre.

Pese a todas las restricciones que podamos hacer, la deformación inmanente de la fe que constituye la masa de las experiencias

26 Cfr. DANIÉLOU, Dios y nosotros, 43-56.

27 Luis F. LADARIA, Jesucristo, salvación de todos, Madrid, San Pablo, 2007, 45. 
religiosas paganas y neopaganas no deja de ser fe. Mantiene una cierta gramática de humanidad en relación, aunque ésta acontezca ahora desde una inteligencia y una conciencia herida como consecuencia del pecado ${ }^{28}$. Así, la realidad no deja de conservar un fondo último donde todo se sustenta y es base de las manifestaciones de lo divino con las que el hombre capta y define esa realidad que está ahí de modo incuestionable y absolutamente presente. Lo que sea el hombre no puede pensarse sin estas formulaciones de lo divino. Como recoge Juan Carlos Carvajal, el hombre es "referencia a Dios incomprensible como propia naturaleza, y el rechazo o aceptación determina nuestra existencia. La naturaleza humana no es ajena a Dios: en su fondo finito se halla remitida al infinito que la sostiene, y su finitud se construye en misterio porque colinda con el misterio incomprensible de la infinitud. La respuesta a la manifestación de Dios es la conversión" 29 . De tal manera que lo divino no constituye una realidad deductiva al margen de la experiencia, sino parte de su experiencia; pues "el hombre no inventa esta presencia de lo divino, sino que la encuentra en su vida" ${ }^{30}$. En efecto, pese a todo, lo divino es una brecha en su propia condición. Esta original elaboración de la cuestión nos permite apuntar a una gramática de lo divino en lo humano que nos abre en esperanza sobre el futuro de la fe.

Presentemos ahora la cuestión inicial ¿cómo mostrar a Dios en tiempos de increencia? desde una variación eidética: ¿Podría el hombre pensarse sin Dios? El mundo contemporáneo, al negar la trascendencia, parece dar una respuesta afirmativa. Es posible ser hombre sin Dios; más bien, parecería que es en estos momentos de la muerte de Dios cuando más propiamente el hombre se piensa y se posee. En tal caso el hombre moderno habria desvelado todos los misterios de su existir: el origen de mi ser, el sentido del existir, y el destino último. En cambio, el mundo contemporáneo parece indicarnos lo contrario: "Desde mitad del siglo XIX a mitad del siglo $\mathrm{XX}$ hemos vivido esa enconada lucha de la inteligencia humana por entender el mundo sin Dios, por realizar un mundo más humano

${ }_{28}$ Cfr. Salvador PIÉ-NINOT, La teología fundamental, Salamanca, Secretariado Trinitario, 2002; 262.

29 Juan Carlos CARVAJAL BLANCO, Lógica de la existencia y lógica de la fe, Salamanca, UPS, 2003. 129.

30 ZAMBRANO, El hombre y lo divino, 32. 
sin Dios, por asegurar el futuro sin Dios. Al final del proceso se comprueban dos cosas. Primera, que se ha intentado explorar todos los campos desde los que se podía argüir la no existencia, la no necesidad, la no fecundidad de Dios, más aún, su carácter nocivo. Segunda, que tras todos esos intentos, el hombre no ha borrado a Dios de la memoria y del deseo humano, que Dios vuelve como pregunta necesaria y como respuesta posible, que el mundo no ha sido renovado, que con la eliminación de Dios de las conciencias es el propio hombre el que entra en peligro"31. Luego la primera tarea que se ha de emprender si queremos presentar el misterio de Dios en este mundo con nuevos perfiles no está propiamente en un mero cambio de lenguaje o de recursos en el decir sobre Dios, sino en el hombre y su última verdad constitutiva. Respondamos al qué radical del hombre, y tendremos el por qué de Dios en él. Dios es la única respuesta capaz de satisfacer al qué radical del hombre.

\section{A VUELTAS CON EL DIOS DESCONOCIDO}

En tales circunstancias, donde el fenómeno de la increencia apunta a una quiebra interior de la persona en su dimensión relacional de sentido, y su consecuente deformación idolátrica, nos preguntamos cómo abordar hoy la urgente tarea de la evangelización. La tradición viva de la Iglesia nos responde. No es la primera vez que la Iglesia se encuentra con la increencia y la idolatria. Las primeras experiencias de anuncio del Evangelio fuera de Palestina tuvieron como escenario un ambiente idolátrico y un tono humano, en cierto sentido, caracterizado por la increencia. Singularmente el proceder del Apóstol Pablo en Atenas, como experiencia patrón, bien pudiera ofrecernos alguna luz para nuestro hacer presente.

Cuando san Pablo alcanza el Areópago ateniense toma como punto de apoyo argumentativo para su anuncio de Jesucristo 'Al dios desconocido'. Mediante este recurso, el Apóstol no pretende presentar a Jesús como una divinidad más a sumar al Panteón clásico, pero desconocida hasta el momento, sino que su pretensión es predicar al Dios verdadero. En cierto modo, más que hablar

31 GONZÁLEZ DE CARDEDAL, La entraña del cristianismo, 110. 
de un dios desconocido, el discurso paulino apunta a la verdad desconocida de Dios: "El Dios que hizo el mundo y todo lo que hay en él, y que es el Señor del cielo y de la tierra no habita en templos construidos por mano de hombre; tampoco tiene necesidad de que los hombres lo sirvan, pues él da a todos la vida, el alimento y todas las cosas. Él creó de un solo hombre todo el linaje humano (...) con el fin de que buscaran a Dios, por si, escudriñando a tientas, lo podían encontrar. En realidad no está lejos de cada uno de nosotros, ya que en él vivimos, nos movemos y existimos. Así lo han dicho alguno de vuestros poetas: Somos de su linaje. Por tanto si somos linaje de Dios, no debemos pensar que la divinidad se parezca a oro, plata, piedra o escultura hecha por arte y genio humano. Ahora, sin embargo, pasando por alto los tiempos de la ignorancia, Dios hace saber a los hombres que todos, en todas partes, han de convertirse, ya que él ha establecido un día, en el que va a juzgar el universo con justicia por medio de un hombre designado por él, a quien ha acreditado ante todos resucitándolo de entre los muertos" (Hch 17, 24-31). Dios creador y creación, trascendencia divina, fraternidad humana y linaje de Dios constituyen los elementos nucleares del rostro desconocido del Dios al que ya, de alguna manera, reconocían en su desconocimiento bajo el velo del altar 'Al dios desconocido'.

El Apóstol Pablo no niega la religiosidad del pueblo griego, es más, pondera su carácter "extremadamente religioso", que le lleva a estar abierto a una divinidad desconocida. No obstante, la ubicación del altar 'al dios desconocido' entre los demás monumentos sagrados existentes en la ciudad habla de una disposición religiosa en suma y no en trascendencia. De ahí que el Apóstol Pablo presente su misión como un abrir el entendimiento de los atenienses desde aquello que 'veneran sin conocerlo' a la verdadera proporción de la verdad de Dios en su misterio trascendente e inefable: Jesucristo. Mas no estamos, en cualquier caso, ante un acrecentamiento de la experiencia religiosa por acumulación, ni siquiera ante el desarrollo de aquello que se encontraba germinalmente en los cultos paganos. Ante la absoluta novedad del mensaje cristiano, las antiguas religiones quedan canceladas porque los limites de su propia condición han quedado desvelados en Jesucristo, Palabra definitiva del Padre. Es Dios mismo, al hablar a los hombres en Jesucristo, quien cancela los tiempos de la ignorancia. Hay una 
ruptura, por salto cualitativo, sobre la historia de las religiones que no permiten la asimilación del cristianismo, ya sea por evolución o por sincretismo. Tal como expresa Daniélou: "Ni el cristianismo ni el judaísmo son manifestaciones de una evolución inmanente del genio religioso de la humanidad, del que no serian más que expresiones relativamente superiores"32.

Sin embargo, no deja de ser irónico que, pese haber ponderado la religiosidad del pueblo griego, lo único salvable del paganismo sea para san Pablo, precisamente, lo que desconocen de Dios. Éste no es un dato menor. De hecho, las posibilidades de diálogo entre la novedad de Cristo y el mundo greco-romano no se establecieron sobre la religión, sino sobre la búsqueda de la verdad de Dios, espacio común de comunicación que hará posible el diálogo con la filosofia griega. De ahí que Pablo presente 'al dios desconocido' en referencia bíblica y filosófica: Sobre el Dios creador en relación a la enseñanza de los pitagóricos, que fueron los primeros en hablar de cosmos como mundo ordenado, y recuerde a Platón en su logos padre y creador; la trascendencia de la divinidad se apoya en los estoicos que enseñaban que no debía construirse templos de los dioses; y finalmente la cita de Arato de Solos en su obra cosmológica Fenómenos, "Pues somos linaje suyo", para hablar del entronque divino del hombre, que le eleva sobre el resto de las cosas creadas, al tiempo que denuncia el carácter idolátrico de un culto hechura de manos humanas. No obstante, la filosofía griega tampoco queda muy bien parada. El autor de los Hechos de los Apóstoles nos describe a los atenienses como un pueblo ávido de novedades, con predominio de epicúreos y estoicos (cfr. Hch $17,18)$. Dos corrientes filosóficas contrarias en sus postulados morales, pero idénticas en su umbral antropológico inmanente, y una sed de novedad que, como recuerda Ortega, impide la búsqueda de las razones últimas, la verdad. De ahí que la plena revelación del misterio divino en Jesucristo también conlleve una iluminación de la propia razón del hombre, que la hace recrecerse hasta alcanzar un horizonte de trascendencia antes desconocido, que va más allá de ella pero que la plenifica y le evita agostarse en sí misma.

32 DANIÉLOU, Dios y nosotros, 42. 
La experiencia paulina en el Areópago lejos de estar agotada, ofrece una inusitada actualidad. La exclusión de la trascendencia por absorción de la inmanencia del hombre moderno y contemporáneo ha generado un proceso de transferencia y proyección de la vivencia religiosa en multiplicidad de versiones de carácter idolátrico. Una vez más, la negación de la razón humana para acoger el misterio que se le descubre a través de la creación y en su misma humanidad, pervierte el orden de la revelación cósmica, afecta a la condición misma del hombre, reduciéndolo a un ente orgánico más, sometiéndolo al orden de sus leyes físicas, y le impide alcanzar la verdad de Dios. Estamos nuevamente ante el dios desconocido (el Dios verdadero que los hombres desconocen); aunque en esta ocasión sus perfiles sean mucho más crudos y radicales, pues no estamos exactamente ante un retorno del paganismo clásico, como ya vimos, sino ante un hombre que se ha tornado dios, ocupando su espacio. Propiamente hemos pasado del dios desconocido al dios suplantado o usurpado. Pese a todo, desde el propugnado vacío de Dios, su misterio sigue constituyendo una presencia, como una huella en la arena o una sombra en el camino de la humanidad, que remite y reclama a la única verdad de presencia capaz de colmarla.

La tarea del creyente será pues, siguiendo la estela de san Pablo en el Areópago, mostrar al hombre de la inmanencia el carácter idolátrico, falso, de sus remisiones y proyecciones pseudo-religiosas; al tiempo que desvelar el carácter quebrado de su razón cerrada sobre sí, que no reconoce más realidad que la que puede doblegar a su exigencia de inteligibilidad racionalpositivista, abriéndola al misterio desde la vivencia de sus propios límites comprensivos. La negación de Dios en la filosofia moderna y contemporánea no es una consecuencia inherente al ejercicio del pensamiento, sino la constatación de la existencia de un falso ejercicio de la filosofia. De tal modo que ante la cuestión Dios "no hace crisis, por tanto, la filosofia como tal, sino un determinado uso de la misma"33, que pretende reducirlo todo a conceptos dentro de un sistema según la disciplina de su misma inteligibilidad. Tal

33 Adolphe GESCHÉ, Dios para pensar, T. II: Dios y el cosmos, Salamanca, Sígueme, 1997; 63. 
pretensión, a juicio de Daniélou, es contraria al ser mismo de Dios y constituye una ilusión idolátrica, ya que "el Dios vivo no puede circunscribirse con la inteligencia, y que un Dios que fuera completamente inteligible para el hombre seguramente no sería el verdadero Dios" ${ }^{34}$. De modo que, tanto el rechazo de Dios como su encuentro nuca puede ser el resultado final del proceder de la razón pura; pues "su existencia no depende de que se someta a las leyes de la lógica de la razón humana, a la medida de sus deseos" ${ }^{35}$. El desconcierto del misterio en su trascendencia es la señal más elocuente del conocimiento del verdadero Dios. Pues como señala Daniélou, "Dios es aquel a quien el espíritu no puede poseer, y que sólo puede ser conocido por el testimonio que da de sí mismo"36. De ahí que cuando el hombre no está sostenido por la revelación sólo puede llegar a afirmaciones vacilantes o contradictorias. De tal modo que la razón es la tensión de lo humano que sólo la revelación puede corresponder adecuadamente como afirma Pié-Ninot: "Dios creando al hombre le dio desde el principio la capacidad para recibir la revelación divina, para poder escuchar la palabra de Dios, y para poder acogerla obedientemente de acuerdo con la razón" 37 .

Estos límites de su propia racionalidad sitúan al hombre ante el misterio de su realidad; pero no como impotencia para llegar más allá, sino como la textura de su singular condición: "Contraría al hombre en su pretensión de encerrarse en sus propios límites, de bastarse a sí mismo. Le hace ver el carácter precario y amenazado de su existencia. Lo descentra de sí mismo y lo hace salir de sus caminos" ${ }^{38}$. En contra de la conclusión racionalista, los límites que encuentra la razón en su ejercicio ante la pregunta última y definitiva no anula su ser, no la descalifica, sino que la resitúa ante su verdadera proporción. El encuentro con Dios obliga a la inteligencia a una conversión radical mediante la descentración de sí misma en trascendencia; inicio del conocimiento mismo de Dios.

DANIÉLOU, Dios y nosotros, 76.

MARTÍN VELASCO, ¿Dónde está Dios? Itinerarios y lugares de encuentro, 44.

DANIÉLOU, Dios y nosotros, 117.

37 PIÉ-NINOT, La teología fundamental, 258.

38 DANIÉLOU, Dios y nosotros, 143. 
La configuración actual de lo divino ofrece en su deformada reducción una cierta verdad de Dios, que reclama desde sus limitaciones la manifestación de la verdad del misterio de Dios en su totalidad. Porque como escribe Santiago del Cura, "es posible que en estas nuevas religiosidades haya una auténtica búsqueda de lo divino, más allá de las representaciones esteriotipadas del Dios de la religiones monoteístas. Pero hay motivos para considerarlas como formas de religiosidad sin un Dios personal, desconocedoras de su verdadera trascendencia"39. Así, se podría hablar de las configuraciones inmanentes de lo divino en correspondencia con el deseo natural de ver a Dios, y estaría justificado presentar a Dios en continuidad con los deseos y necesidades de nuestro corazón. Pero, este ajuste entre necesidad y satisfacción, lejos de constituir un criterio definitivo de autenticidad de las experiencias religiosas actuales basadas en la psicoafectividad, parece indicar más bien su deficiencia. Pues tal como señala Del Cura: "Si Dios es solamente el recurso para ser nosotros mismos, para lograr nuestra propia identidad, para armonizar tensiones o para dominar el desafio de la existencia, bien podría tratarse de un Dios domesticado, descrucificado y evangélicamente irreconocible" ${ }^{40}$. Más bien, la objetividad de la existencia de Dios y su verdad se impone "cuando contradice nuestras aspiraciones, cuando su realidad desconcierta nuestra inteligencia y su voluntad desbarata nuestros proyectos, cuando nos vemos obligados a reconocerlo en cierto modo a pesar de nosotros mismos"41.

La verdad del Misterio de Dios no se agota en las satisfacciones de nuestras expectativas (reducción inmanente del Misterio y deformación inmanente de la fe), si no que su índice de verdad viene marcado por la remisión al mismo Dios como don último, que implica alteridad respecto a todo lo creado: su trascendencia inefable, el totalmente Otro. Tal es su complexión inmanentetrascendente: El Dios que está en todas las cosas, las trae al

39 Santiago DEL CURA ELENA, A tiempo y destiempo. Elogio del Dios (in)tempestivo, 367.

40 Santiago DEL CURA ELENA, A tiempo y destiempo. Elogio del Dios (in)tempestivo, 370.

41 DANIÉLOU, Dios y nosotros, 77. 
ser, las conforma en su ser, y el Dios que es el totalmente otro, el absolutamente trascendente a cualquier afirmación de este mundo. Esta doble complexión del misterio salvaguarda la trascendencia de Dios en el interior de su inmanencia: "Es la barrera infranqueable que impide que la religión auténtica caiga en el panteísmo. Mantiene el abismo que separa al Creador de la criatura en el interior del don que el creador hace de si mismo a la criatura. Manifiesta la gratuidad de Dios, manifestando que la vida divina en el hombre una realidad extraña y no una propiedad natural. Le da también todo su valor, porque el valor del don que Dios hace de sí mismo sólo aparece si antes se ha vislumbrado algo de lo que Dios es en sí mismo"42.

Frente a cualquier reducción de Dios a principio conceptual, Dios se presenta en su verdad como ser personal, vivo y actuante; $Y$ frente a la revelación cósmica, Dios se manifiesta en acciones únicas y universales que hace del hecho un acontecimiento porque supone un salto sustancial sobre el suceder cósmico, aunque lo contemple en su base como gramática ${ }^{43}$. En este sentido, Creación y Encarnación constituyen los abismos entre el cristianismo y cualquier experiencia religiosa de matriz inmanentista. Afirmar que el universo ha sido creado por Dios es afirmar, que su lógica depende de una lógica de sujeto, o sea de una lógica de don y libertad. La naturaleza queda liberada del fatum propio de la necesidad material y sus leyes. "El hecho de depender de Dios, significa para la creación que, en vez de quedar abandonada al anonimato, al azar o a la necesidad, está confiada al cuidado de un Sujeto, entendiendo por tal un ser personal foco de inteligencia $\mathrm{y}$ de libertad no sometido al destino y que, sin embargo, sigue siendo siempre dueño de la situación"44. Si Dios crea libremente, Dios crea porque quiere como acto de voluntad y de amor a un tiempo: "Vio Dios cuanto había hecho, y todo estaba muy bien" (Gn 1, 31). Para el Génesis en el principio de todo cuanto existe está la libertad, la persona que se entrega en amor, la iniciativa

42 DANIÉLOU, Dios y nosotros, 143.

43 Cfr. PIÉ-NINOT, La teología fundamental, 243; DANIÉLOU, Dios y nosotros, 111113.

44 GESCHÉ, Dios para pensar, T. II: Dios y el cosmos, 82 
que desencadena iniciativas y sólo tras ellas viene la materia, la acción y la respuesta humana. En el principio era el amor, el sentido, la gratuidad, el don. Por el hecho de que el ser que poseo no me pertenezca, sino que sea recibido de otro, no significa que mi ser no sea propiamente yo. Mi ser es totalmente gratuito respecto de mi mismo, yo no soy mi origen. Y respecto del misterio de donación al que me remite ya somos dos, mi existencia es en sí misma relación. Existo porque soy amado, y existir para mí será responder a esa gracia del amor en amor. "De este modo, el ser creado no es desposeído de la existencia como dice Sastre sino que soy desposeído de mi voluntad de autosuficiencia" ${ }^{45}$. Un acontecimiento revelador del misterio personal en Dios, que culminará en el encuentro definitivo en Jesucristo, rostro a rostro, el hombre y Dios.

El diálogo sobre el dios desconocido y lo que desconocemos de Dios, aunque en ocasiones se produzca desde la tozudez de la negación (increencia) o su deformación idolátrica, puede ayudarnos a los creyentes a adentrarnos en ese Misterio de Dios que sobrepasa todo, que pese a nuestras afirmaciones siempre queda más allá de nuestros conceptos. En este sentido, los rechazos y críticas que se puedan recibir pueden valorarse como elemento purificatorio de todas nuestras imágenes, conceptos y vivencias de Dios. Por su parte, la ciencia teológica tendrá que realizar una doble misión: por una parte desenmascarar el proceso de transmutación del Dios cristiano en objeto, y finalmente en idolo pagano; y por otro, volverse hacia si para preguntarse cómo ha transmitido el Evangelio, si ha anunciado tanto al Dios creador como al Dios redentor, la gloria de Dios y la vida consiguiente del hombre. Lo que constituye para la misma Iglesia una llamada de atención hacia lo que Santiago del Cura denomina autosecularización por acomodación ${ }^{46}$ como asunción del paradigma 'como si dios no existiera', llevando a la teología y a la misma fe a su autodisolución.

45 DANIÉLOU, Dios y nosotros, 109.

46 Cfr. Santiago DEL CURA ELENA, A tiempo y destiempo. Elogio del Dios (in)tempestivo, 339-351. 


\section{JESUCRISTO DEFENSA Y DEFENSOR DEL MISTERIO DE DIOS Y DEL HOMBRE}

Del proceso de la modernidad y sus consecuencias, los creyentes podemos aprender críticamente cómo plantear el anuncio del Evangelio sin renunciar a las exigencias de autenticidad de la fe, ni obviar las notas singulares del hombre contemporáneo afectado en su estructura antropológica de fe por una deformación inmanente.

a) No agotar la presentación de Dios en formulaciones discursivas. Nuestro hablar de Dios no puede constreñir el Misterio de Dios en ideas, formulaciones conceptuales, agotándolo y sometiéndole al régimen de nuestra imposición lógica. Tal cosa sería una pretensión idolátrica que va contra la verdad de Dios en su misterio, y es incapaz de saciar adecuadamente la íntima verdad humana. "Dios no es objeto conquistable por nuestro esfuerzo, sino la fuerza que nos mueve a buscarlo" 47 . Cualquier decir sobre Dios debe "mantenerle en su derecho de ser lo que él es, sin ponerle por delante nuestras definiciones o nuestras prohibiciones" ${ }^{\prime 8}$. Dios debe llevar su propia iniciativa y defensa.

b) Acoger a Dios tal cual ha querido mostrarse. No tenemos posibilidad de conocer quién es Dios en su misterio trascendente, si Él mismo no se mostrase a los hombres, ya sea desde su manifestación en las criaturas, ya sea en el mismo cuño humano, ya sea finalmente con su plena Revelación. Esto obliga a la disposición de un conocimiento liberado de ideas preconcebidas. Dios nunca aparece como un resultado de mi ejercicio deductivo. Sentencia Gesché, "hemos de aprender de Dios lo que él es" 49 . Esto es, mostrar a Dios desde lo que Dios mismo ha querido mostrarse y según ha querido mostrarse. De tal modo que sería falsa la pretensión humana de alcanzar una comprensión neutra de la naturaleza divina. Tras la encarnación del Verbo Eterno de Dios en una carne como la nuestra no es posible responder a lo que sea la naturaleza

\footnotetext{
47 MARTÍN VELASCO, ¿Dónde está Dios? Itinerarios y lugares de encuentro, 52.

48 GESCHÉ, Dios para pensar, T. II: Dios y el cosmos, 51.

49 GESCHÉ, Dios para pensar, T. II: Dios y el cosmos, 113
} 
de Dios si no es a partir de Jesucristo ${ }^{50}$. Cualquier otro camino de búsqueda del Misterio de Dios se manifiesta ahora insuficiente; Pues tal como expresa Ladaria "La revelación del misterio de Dios en toda su profundidad acaece únicamente en Jesús" ${ }^{51}$.

c) Jesucristo abre el misterio de Dios y del hombre. Cuando Caledonia perfila el misterio cristológico en sus dos naturalezas (Dz 301), presenta a Jesucristo como verdadero Dios y verdadero hombre. Sus palabras nos sirven para afirmar en Jesús no sólo la verdad de su condición, sino también la unidad, en su persona, de la verdad del hombre y de la verdad de Dios. De tal manera que Jesucristo no sólo es verdaderamente Dios y verdaderamente hombre, sino que en él acontece la plena manifestación del hombre y de Dios en su verdad. Ambos elementos dejan de ser en la persona de Jesucristo binomio Dios-hombre para constituirse en un único misterio, que ilumina totalmente al hombre en su verdad interior, y en su dimensión relacional de sentido en trascendencia. Jesucristo al desvelar en el misterio de su persona la verdad una del hombre y de Dios, muestra a un tiempo la verdad del misterio divino/humano y el camino a recorrer para la evangelización. De tal modo que todo hablar de Dios es una inteligencia del acontecimiento de Cristo ${ }^{52}$. Será desde el encuentro con Jesucristo donde el hombre descubra la verdad del misterio de su humanidad y del misterio del Dios que sale a su paso, la íntima constitución de su ser en relación, y el sentido de su existencia. En un doble movimiento: ascendente, desde nuestra experiencia de encuentro con Él hasta su persona; y descendente, desde su persona a la vivencia de nuestro encuentro. Ambos movimientos se iluminan mutuamente.

Pero con lo dicho hasta el momento, aún no se ha respondido al por qué en Jesucristo queda desvelado a un tiempo el misterio de Dios y el misterio del hombre, y en consecuencia cómo constituye su persona misma el gran y único Misterio que revela a Dios, al tiempo que ilumina la condición humana. El prólogo de san Juan

50 Cf. GESCHÉ, Dios para pensar, T. II: Dios y el cosmos, 65.

51 Luis F. LADARIA, El Dios vivo y verdadero, Salamanca, Secretariado Trinitario, 1998; 24.

52 Cf. CARVAJAL BLANCO, Lógica de la existencia y lógica de la fe, 128. 
nos da la respuesta. El evangelista describe el misterio de la persona de Jesucristo desde un acontecimiento que es a un tiempo histórico y eterno: "En el principio existía la Palabra y la Palabra estaba junto a Dios, y la Palabra era Dios. Y la Palabra se hizo carne y puso su morada entre nosotros y hemos contemplado su gloria" (Jn 1, 1.14). El misterio eterno e insondable, por cuanto todo existe, ha entrado en el tiempo y en el espacio de los hombres, tomando nuestra propia carne y habitando entre nosotros. "Es un mismo Verbo de Dios quien creó al mundo y al hombre en el origen, y quien, en la plenitud de los tiempos, vuelve a recobrar a su criatura para restaurarla y comunicarle la incorruptibilidad" 53 . Igualmente, en su primera carta, san Juan abunda en la misma experiencia del Dios inefable en su misterio transcendente, al que sin embargo ha oído, ha visto y pudo palpar: "Lo que existía desde el principio, lo que hemos oído, lo que hemos visto con nuestros ojos, lo que contemplamos y tocaron nuestras manos" (1Jn 1,1). No estamos ante un concreto universalizado, fruto de la proyección de inquietudes humanas, o la plasmación de lo mejor de nuestra condición tal como propugnó Freuerbach. La afirmación joánica discurre justamente en la dirección contraria: partiendo de un particular concreto donde se revela una pretensión universal a partir de sí mismo. Jesucristo es el universal concreto de modo que "en el acontecimiento único de Jesucristo se halla revelado, en cuanto es posible, pero con valor de universalidad, la persona, la historia y la naturaleza de Dios"54. La persona de Jesús de Nazaret es la Palabra que existía desde el principio, a la que sin embargo hemos oído, visto con nuestros ojos, y tocado con nuestras manos. "La realidad de Jesús es un hecho no un invento, por eso tiene que ser encontrada y descubierta y nunca puede ser construida" 55 .

d) Evangelizar en principio de Encarnación. Dios mismo se nos ha revelado entrando en nuestro tiempo, haciendo presencia en nuestro espacio, y siendo uno con el hombre. El hecho histórico del nacer es el lugar propio del acontecimiento: la Encarnación. Esta será la vía de acceso al misterio de quién es Dios tal como recoge

53 DANIÉLOU, Dios y nosotros, 155.

54 GESCHÉ, Dios para pensar, T. II: Dios y el cosmos, 56.

55 GONZÁLEZ DE CARDEDAL, La entraña del cristianismo, 441. 
Gesché: "No es a partir de una idea de Dios, sino a partir de eso concreto que es Jesús, de eso histórico que es la encarnación como podemos aprender lo que es Dios"56. Rechazar la Encarnación como el modo propio de la manifestación de Dios es renunciar a conocer a Dios tal como Él ha querido que se le conozca. "Al hacerse carne e historia en Jesús de Nazaret, Dios mismo ha llegado a ser en el sentido más radical de la expresión un Dios 'por nosotros' (pro nobis). $\mathrm{Y}$ en esta historia salvifica es donde se nos da a conocer el 'en si' (in se) de la realidad y de la vida intradivina"57.

En Jesucristo, el misterio de Dios no nos da un conocimiento de algo distinto de él, como tampoco nos dispensa unos dones distintos a él. "Si no se nos diera como es, no se nos daría él mismo. Si no se manifiesta como es, no se nos revelaria"58. Estamos ante la manifestación de Dios mismo en la donación de sí tal como confesamos en el credo: Propter nos homines et propter nostram salutem $^{59}$. De tal manera que la actuación de Dios en la historia (creación, encarnación, redención) no puede ser tomada como un accidente. "La revelación de Dios, en cuanto revelación salvífica en sí misma, acontece en la realización misma de nuestra salvación por obra de Cristo. Los dos aspectos no se pueden separar"60. El Vaticano II estableció claramente esta conexión entre revelación de Dios y donación de la verdad salvífica (cfr. DV 2.6). Como presenta Juan Carlos Carvajal: "Es un solo y mismo acto por el que Dios hace conocer y salva a los hombres" ${ }^{\text {" }}$.

e) El anuncio del Dios verdadero, es Trinidad. El misterio de Jesucristo está inserto en la estructura de la Trinidad. Lo contrario sería una reducción del Misterio desvelado en su persona para caer en cristolatría. "La verdadera cristología debe ser trinitaria, y la teología trinitaria ha de ser entendida cristológicamente. Entre el Hijo en la vida eterna de Dios y el Hijo en la historia terrestre de

\footnotetext{
GESCHÉ, Dios para pensar, T. II: Dios y el cosmos, 66.

Santiago DEL CURA ELENA, A tiempo y destiempo. Elogio del Dios (in)tempestivo, 373.

LADARIA, El Dios vivo y verdadero, 30.

Cfr. PIÉ-NINOT, La teología fundamental, 250

LADARIA, El Dios vivo y verdadero, 25.

61 CARVAJAL BLANCO, Lógica de la existencia y lógica de la fe, 125.
} 
Jesús se da una íntima correspondencia"62. De ahí que se deba evitar la separación entre cristología y doctrina trinitaria tanto en la teología como en el anuncio de la fe. "El teismo cristiano consiste propiamente en el Dios trinitario, y éste sólo nos es conocido en Jesucristo por revelación"63. Este es el misterio propiamente dicho de Dios, la Trinidad de las Personas. Un misterio totalmente inaccesible a la razón humana. "Sólo con la revelación acaecida en Cristo tenemos acceso al conocimiento del Dios uno y trino. Nuestro punto de partida no puede ser por tanto más que la economía salvífica y en concreto cuanto el Nuevo Testamento nos dice sobre Jesús"64. De tal modo que "toda la historia de la salvación puede considerarse un desvelamiento progresivo de la Trinidad inefable" aunque sin identificarse con el desarrollo de la economía de la salvación ni agotarse en ella. "La Trinidad inmanente no se realiza ni se disuelve en la economía" 66 al modo hegeliano donde el Espíritu Absoluto se recobra a sí mismo en la historia ${ }^{67}$. Al comunicarse al hombre, escribe Ladaria, "la Trinidad sigue siendo un misterio. Ella no se adapta al hombre, sino que eleva al hombre por encima de sí mismo y lo adapta a ella"68.

¿Y el hombre? ¿Cómo entender que en Jesucristo se revela la verdad del hombre? Continuando con el prólogo de san Juan, el evangelista no sólo presenta el acontecimiento de la encarnación del Verbo, sino que pone en relación directa la Palabra que existía desde el principio con todo cuanto existe: "todo se hizo por ella y sin ella no se hizo nada de cuanto existe"(v.3), y singularmente la creación del hombre: "En ella estaba la vida, y la vida era la luz de los hombres" (v.4) y "La Palabra era la luz verdadera que ilumina a todo hombre que viene a este mundo" (v.9). De tal manera que

62 COMISIÓN TEOLÓGICA INTERNACIONAL, Teología-cristología-antropología (1981), en Cándido POZO (ed). "Documentos 1969-1996. Veinticinco años de servicio a la teología", Madrid, BAC, 1998; 258.

63 COMISIÓN TEOLÓGICA INTERNACIONAL, Teología-cristología-antropología (1981), 248.

64 LADARIA, El Dios vivo y verdadero, 23.

65 DANIÉLOU, Dios y nosotros, 153.

66 LADARIA, El Dios vivo y verdadero, 32.

67 Cfr. COMISIÓN TEOLÓGICA INTERNACIONAL, Teología-cristología-antropología (1981), 250.

68 DANIÉLOU, Dios y nosotros, 161. 
la encarnación del Verbo no cosiste sólo en la asunción de la naturaleza humana por parte del Verbo eterno, sino que en su Encarnación viene a algo que le es propio. En la carne histórica de Belén, la humanidad puede reconocerse en el recién nacido, no sólo por solidaridad ante lo humano, una humanidad como la nuestra, sino porque su humanidad descubre las proporciones de la nuestra. De ahí que como señala el Vaticano II "el misterio del hombre sólo se esclarece en el misterio del verbo encarnado" (GS 22).

La iluminación de nuestra humanidad en la humanidad de Jesucristo es doble: Por una parte, desde dentro, como reflejo de lo humano universal que cada uno de nosotros lleva dentro en una realidad particular indeducible, irreductible a lo anteriormente conocido, no sometible a otras formas de humanidad instaurada. Y por otra parte, desde fuera, su trascendencia absoluta le permite la inserción en la realidad humana acogiéndola, apropiándosela y haciéndola ser a ella en forma insospechada de perfección. En este sentido, podemos decir que Jesucristo más que modelo de vida constituye la verdadera fuente de vida.

El hombre creado a imagen y semejanza de Dios alcanza por la encarnación del Hijo de Dios la invitación a la comunión divina trinitaria, siendo hijos en el Hijo. "Lo que todos los hombres, de modo implícito, buscan, desean y esperan, es tan trascendente e infinito que sólo puede encontrarse en Dios. La verdadera humanización del hombre, por ello, alcanza su culmen en su gratuita divinización, o sea, en su amistad y comunión con Dios, por la que el hombre es hecho gratuitamente templo de Dios y disfruta la inhabitación del Padre y del Hijo, y del Espíritu Santo"69. Como señala Daniélou, "esta obra de la redención no es solamente trinitaria por ser obra de las Tres Personas, sino también porque introduce a la humanidad, por mediación de Jesús, en la participación de la vida de las Tres Personas. Es el misterio de la adopción filial que es el término de la obra divina"70. De tal modo que la perfección de la

69 COMISIÓN TEOLÓGICA INTERNACIONAL, Teología-cristología-antropología (1981), 252.

70 DANIÉLOU, Dios y nosotros, 159. 
humanidad que encuentra el hombre no es sólo exterior mediante un perfeccionamiento por imitación de Jesucristo, sino interior por la adopción filial. Así, la remisión del pecado y de la muerte constituye una acción aparejada al primer efecto de la salvación: ser constituidos en hijos de Dios. Esta liberación ya no es de las cosas, ni de las circunstancias esclavizantes de la humanidad, sino incluso de la libertad del hombre en su relación con Dios. La elevación a condición de hijo otorga al hombre un estatus nuevo ante Dios. De tal manera que la acción divina acontecida en Cristo otorga al hombre máxima apertura de su afirmación humana como hijo de Dios. "La deificación entendida correctamente hace al hombre perfectamente humano: la deificación es la verdadera y última humanización del hombre" ${ }^{\prime 1}$.

Ahora bien, cómo se establece la conexión entre Jesucristo y el hombre. El hombre ontológicamente es una pregunta, no sólo un ser que pregunta sino más radicalmente un interrogante para sí mismo como declara el Concilio Vaticano II. Al abordar la pregunta por el sentido de la vida, de alguna manera el ser humano se sitúa al límite de su propia comprensión porque su preguntar ha terminado por superarle y envolverle ${ }^{72}$. Hemos pasado de la inteligencia del hombre como problema al ámbito del misterio de lo humano. Sólo en esta esfera, el hombre supera la cosificación y adquiere la contemplación de su propia dimensión no reductible: Ser persona. No obstante, el sentido de la vida no se responde sino que se encuentra en otro que se nos da, en alguien en quien nos podemos reconocer como preexistidos, que nos ilumina. Este dato común de la experiencia inmediata nos lleva a la base de la misma persona, donde el yo no se constituye sólo, ni desde su soledad sino desde dentro por la acción del otro. Pues tal como señala Cardedal: "Los hombres necesitamos que alguien nos previva para descubrir lo que ser hombre necesita y exige, hasta donde se debe extender y hasta qué bordes no se puede llegar. No hay una metafisica ni una matemática normativa de lo humano, que nos den dicho de antemano lo que es ser hombre: vamos aprendiendo de nuestros

\footnotetext{
71 COMISIÓN TEOLÓGICA INTERNACIONAL, Teología-cristología-antropología (1981), 254.

72 Cfr. MARTÍN VELASCO, ¿Dónde está Dios? Itinerarios y lugares de encuentro, 64.
} 
semejantes lo que es humanidad y lo que es inhumanidad" ${ }^{\text {"3 }}$. E1 ser humano busca la coincidencia de una vida consigo misma, pero siempre a través de Alguien, uno semejante a nosotros que nos realiza. Nos situamos pues ante el encuentro, de persona a persona, y su propia dinámica interna de libertad para acoger o rechazar $^{74}$. "Esa manifestación sólo habrá podido ser reconocida mediante un proceso en el que el sujeto ha puesto en juego su condición de persona y ha reconocido en su interior la presencia que se le anunciaba en la realidad teofánica"75. Este es el espacio adecuado para el encuentro del hombre y el misterio de Dios en rostro humano: Jesucristo.

El encuentro presupone un deseo en la persona que recibe, y la capacidad de reconocer al otro como el deseado, acontece en libertad y requiere el acto de la existencia como diálogo. No sería posible reconocer la plena manifestación de Dios en Jesús sin la luz de la prenoción y el deseo de Dios, luz que vive en el corazón del hombre. Pero una vez acaecido el encuentro con Jesucristo, toda prenoción es superada y alcanza un cumplimiento más allá de todas las fuerzas humanas. La persona se abre admirativamente ante la presencia de lo que ni oído oyó, ni ojo vió, ni mente humana podría concebir; pero que ahora se encuentra ante él. Quienes se han encontrado, de alguna manera, se vinculan existencialmente más allá del acontecimiento primero que los reveló mutuamente como referidos, donde las personas interaccionan haciendo una historia que les es propia porque sin ellos, simplemente, no sería posible. Un proceso personal de conversión hacia la otra persona que tiene forma de consentimiento activo, pero no solitario porque la otra persona, de alguna manera, se hace presente en él. Es la acción de Dios interior al hombre, el Espíritu Santo, quien introduce al hombre en sus caminos. De tal modo que el conocimiento de Dios ya no es algo meramente conceptual o sentimental, sino vital que afecta a la totalidad del hombre, vinculando conocimiento de Dios y construcción de la existencia. "La cercanía de Dios no se alcanza tanto por la capacidad intelectual del hombre cuanto

\footnotetext{
GONZÁLEZ DE CARDEDAL, La entraña del cristianismo, 445.

Cfr. PIÉ-NINOT, La teología fundamental, 253.

5 MARTÍN VELASCO, ¿Dónde está Dios? Itinerarios y lugares de encuentro, 47.
} 
por la conversión del corazón"76. Tal como apunta hermosamente Ratzinger: "Ver a Dios tiene lugar en este mundo en el modo del seguimiento de Cristo" 77 . En este sentido, contemplar a Dios es un acto de toda la existencia, entendiendo ésta como vida en discípulo.

La categoría fundamental ahora es la del testigo. "El Dios que no me necesita y me crea para ser, ser creador y libre en el mundo, se me ha otorgado como amigo y me ha abierto el ámbito de su intimidad. Por ello quien lo ha descubierto, ya no puede pensar en ser sin Dios, ni comprender la persona sin intimidad con Dios" ${ }^{78}$. Será por el testigo cualificado por la vida en el Espíritu Santo y la comunidad eclesial los que sirvan la realidad de la presencia de Dios en el mundo. Su mera presencia creyente constituye un interrogante para sus contemporáneos ante el que se preguntan por qué cree en Dios. Su existencia es provocadora. Tenemos entonces lo que Cardedal ha denominado el contraste irreductible: "Dios, lo más necesario para el hombre, es lo más gratuito; a la vez que lo más gratuitamente otorgado al hombre es lo más necesario. Todo esto se devela en el orden de la inteligencia y se ofrece a la libertad. Con ello se abre el abismo de la posible aceptación o del posible rechazo, de la gracia y del pecado, como formas de opción para ser ante Dios o sin Dios en el mundo"79.

\section{A MODO DE CONCLUSIÓN}

La evangelización es una exigencia que brota de la misma fe. De tal modo que no se hace comprensible una vida cristiana eximida del mandato del Señor: "Id al mundo entero y proclamad el Evangelio", o un lugar geográfico o momento histórico dispensado de su anuncio. En esta labor, el cristiano no está abandonado a su suerte en medio de un entrono adverso, o limitado a sus solas fuerzas, sino que goza de la asistencia del Espíritu del Señor que se nos asegura como don perenne. Y esto es altamente iluminador

76 COMISIÓN TEOLÓGICA INTERNACIONAL, Teología-cristología-antropología (1981), 254.

77 Joseph RATZINGER, Caminos de Jesucristo, Madrid, Cristiandad, 2005; 28.

78 GONZÁLEZ DE CARDEDAL, La entraña del cristianismo, 136.

79 GONZÁLEZ DE CARDEDAL, La entraña del cristianismo, 136. 
para afrontar cualquier reflexión sobre el momento presente, porque nos ancla en la esperanza de la fe sobre cualquier dificultad. De tal modo, que la historia de la evangelización no habria que leerla desde las circunstancias contextuales que la hicieron posible hasta el presente, pero que ahora habrían desaparecido, sino desde su propio potencial; aquel que efectivamente le hicieron posible atravesar todas las épocas, y alcanzar a todas las culturas hasta sembrase en todos los continentes. Así, cuando nos preguntamos ¿Cómo mostrar a Dios en tiempos de increencia? reconocemos una situación adversa para la fe, pero no definitoria o bloqueante de toda posibilidad para su nuncio, pues el mismo hecho de interrogarnos nos augura intuitivamente su posibilidad.

Como se desprende del análisis de la modernidad, la increencia es un estado inducido de la persona, al que se llega por imposición comprensiva de una existencia humana autoremitida. Así el hombre de la increencia, en realidad, describe a un hombre abismado en su inmanencia, fruto de sucesivas opciones de un yo en pretensión de absoluto; pero ésta no es su condición natural. Pese a su autoreducción, su humanidad mantiene la estructura básica de sentido donde se asienta el asentimiento de fe. De tal modo que la condición creyente del hombre no es un accesorio opcional de su existencia, sino que por el contrario forma parte de su estructura antropológica constituyente. Lo que va a marcar la diferencia entre unos y otros es la orientación relacional de sentido en inmanencia o trascendencia en la que se produzca. En este sentido, la denominada increencia no contiene dentro de sí tanto una negación del creer como su deformación inmanente. Sólo así es comprensible que un supuesto fenómeno de negación de la creencia venga a ser, en realidad, el magma originante del actual resurgimiento idolátrico.

La prioridad de nuestra labor evangelizadora hoy no consistiria tanto en una modulación del lenguaje para hablar de Dios en términos comprensibles para el hombre contemporáneo, como en una pedagogía de lo humano capaz de abrirle al horizonte de la trascendencia. En esta acción evangelizadora, el hombre de la increencia sólo podrá descubrir como falsas o erróneas sus propias vivencias cuando alcanza ver la verdad de sí mismo en otro semejante, y entender su verdadera vocación de lo humano en la 
autenticidad ontológica de la vida, que se me manifiesta ante mí en el otro. De ahí que el anuncio del Evangelio requiera siempre del encuentro con testigos del mismo, donde el hombre pueda descubrir en otros la propia verdad de su existencia, y así salir de su deformación inmanente. Es así como el propio hombre se torna en camino del Evangelio; y a su vez, el Evangelio constituye el camino del ser hombre; pues sólo en Jesucristo el hombre alcanza su verdad plena y perfecta. La verdad del corazón del hombre trabaja a favor de la evangelización. 